\title{
CORROSION OF GLASS-BONDED SODALITE AS A FUNCTION OF pH AND
} TEMPERATURE.*

Lester R. Morss, Mary Stanley, Chad Tatko, and William L. Ebert

Chemical Technology Division

Argonne National Laboratory

Argonne, IL 60439

For presentation at

Scientific Basis for Nuclear Waste Management XXII

Materials Research Society 1999 Fall Meeting

November 29 to December 3, 1999

Boston, Massachusetts

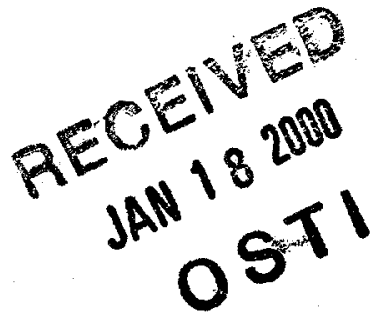

*This work was supported by the U.S. Department of Energy, Nuclear Energy and Development Program, under contract W-31-109-ENG-38. 
This report was prepared as an account of work sponsored by an agency of the United States Government. Neither the United States Government nor any agency thereof, nor any of their employees, make any warranty, express or implied, or assumes any legal liability or responsibility for the accuracy, completeness, or usefulness of any information, apparatus, product, or process disclosed, or represents that its use would not infringe privately owned rights. Reference herein to any specific commercial product, process, or service by trade name, trademark, manufacturer, or otherwise does not necessarily constitute or imply its endorsement, recommendation, or favoring by the United States Government or any agency thereof. The views and opinions of authors expressed herein do not necessarily state or reflect those of the United States Government or any agency thereof. 


\section{DISCLAIMER}

Portions of this document may be illegible in electronic image products. Images are produced from the best available original document. 


\title{
CORROSION OF GLASS-BONDED SODALITE AS A FUNCTION OF pH AND TEMPERATURE
}

\author{
L. R. MORSS, M. L. STANLEY, C. D. TATKO, AND W. L. EBERT \\ Chemical Technology Division, Argonne National Laboratory, Argonne, IL 60439
}

\section{ABSTRACT}

This paper reports the results of corrosion tests with monoliths of sodalite, binder glass, and glass-bonded sodalite, a ceramic waste form (CWF) that is being developed to immobilize radioactive electrorefiner salt used to condition spent sodium-bonded nuclear fuel. These tests were performed with dilute $\mathrm{pH}$-buffered solutions in the $\mathrm{pH}$ range of 5-10 at temperatures of 70 and $90^{\circ} \mathrm{C}$. The $\mathrm{pH}$ dependences of the forward dissolution rates of the CWF and its components have been determined. The $\mathrm{pH}$ dependences of the dissolution rates of sodalite, binder glass, and glass-bonded sodalite are similar to the $\mathrm{pH}$ dependence of dissolution rate of borosilicate nuclear waste glasses, with a negative $\mathrm{pH}$ dependence in the acidic region and a positive $\mathrm{pH}$ dependence in the basic region. Our results on the forward dissolution rates and their temperature and $\mathrm{pH}$ dependences will be used as components of a waste form degradation model to predict the longterm behavior of the CWF in a nuclear waste repository.

\section{INTRODUCTION}

The Electrometallurgical Treatment Program at Argonne National Laboratory (ANL) is developing a conditioning process for treatment of some of the U.S. Department of Energy spent sodium-bonded nuclear fuels that may not be suitable for direct geological disposal. In this process, uranium is electrorefined from spent fuel in a molten $\mathrm{LiCl}-\mathrm{KCl}$ electrolyte, and fission products ( $\mathrm{Rb}, \mathrm{Cs}, \mathrm{Sr}, \mathrm{Ba}$, rare earths) and actinides accumulate in the molten salt. To make the salt acceptable for disposition in a repository, the salt is blended with dried zeolite $4 \mathrm{~A}$, $\mathrm{Na}_{12}\left(\mathrm{AlSiO}_{4}\right)_{12}$, at $500^{\circ} \mathrm{C}$. The salt-loaded zeolite is mixed with a glass binder in a 3:1 mass ratio of salt-loaded zeolite to glass. The mixture is processed at high temperature and pressure to convert the zeolite into sodalite, $\mathrm{Na}_{8}\left(\mathrm{AlSiO}_{4}\right)_{6} \mathrm{Cl}_{2}$, forming glass-bonded sodalite, the ceramic waste form (CWF) [1]. This paper reports the dissolution rates of the sodalite and glass binder components of the CWF, as well as the CWF itself, as a function of temperature and solution $\mathrm{pH}$. These rates will be used to provide parameters for the ceramic waste form model.

Several studies of the effects of $\mathrm{pH}$ and solution conditions on dissolution have been carried out on glasses and aluminosilicate minerals [2-7]. The equation for the dissolution rate of aluminosilicate minerals is based upon the model of Aagaard and Helgeson [8], who postulated the formation of an activated complex at the mineral surface, the decomposition of which is the rate-controlling step in dissolution:

$$
\text { rate }=\mathrm{S}\left\{\mathrm{k}_{0} \cdot 10^{(\mathrm{n} \cdot \mathrm{pH})} \cdot \mathrm{e}^{\left(-\mathrm{E}_{\alpha} / \mathrm{RT}\right)} \cdot\left(1-\mathrm{Q} /\left[\mathrm{H}_{4} \mathrm{SiO}_{4}\right]_{\text {sat }}\right)\right\}
$$

where

$$
\begin{aligned}
\text { rate } & =\text { dissolution rate of material }\left(\mathrm{g} \cdot \mathrm{d}^{-1}\right) \\
\mathrm{S} & =\text { surface area of material }\left(\mathrm{m}^{2}\right) \\
\mathrm{k}_{0} & =\text { rate constant }\left(\mathrm{g} \cdot \mathrm{m}^{-2} \bullet \mathrm{d}^{-1}\right) \\
\eta & =\mathrm{pH} \text { dependence factor } \\
\mathrm{E}_{\mathrm{a}} & =\text { activation energy }\left(\mathrm{kJ} \bullet \mathrm{mol}^{-1}\right), \text { reflecting temperature dependence } \\
\mathrm{R} & =\text { gas constant }\left(8.314 \times 10^{-3} \mathrm{~kJ} \mathrm{~mol}^{-1} \bullet \mathrm{K}^{-1}\right)
\end{aligned}
$$




$$
\begin{aligned}
\mathrm{T} & =\text { absolute temperature, } \mathrm{K} \\
\mathrm{Q} & =\text { concentration of } \mathrm{H}_{4} \mathrm{SiO}_{4} \text { in solution }(\mathrm{mg} / \mathrm{L}) \\
{\left[\mathrm{H}_{4} \mathrm{SiO}_{4}\right]_{\text {sat }} } & =\text { saturation concentration of } \mathrm{H}_{4} \mathrm{SiO}_{4} \text { in solution }(\mathrm{mg} / \mathrm{L})
\end{aligned}
$$

Our study has determined values of $\eta$, the parameter that represents the $\mathrm{pH}$ dependence of dissolution rate, from short-term corrosion tests of glass binder, sodalite, and $\mathrm{CWF}$ in dilute buffer solutions at $\mathrm{pH}$ values between 5 and 10 at 70 and $90^{\circ} \mathrm{C}$.

\section{EXPERIMENT}

Monoliths of each material (glass binder, sodalite, and CWF) were prepared by hot isostatic pressing, cored, and cut into wafers nominally $10 \mathrm{~mm}$ in diameter and $1 \mathrm{~mm}$ thick. The wafers were polished with abrasives to a 600 -grit finish.

The polished pellets were tested according to the MCC-1 procedure [9] in Teflon containers with buffered leachant solutions having the compositions and $\mathrm{pH}$ values shown in Table I. To achieve the ratio of $10 \mathrm{~m}^{-1}$ for the specimen surface area to leachant volume (S/V), a typical wafer with total surface area of $2.00 \mathrm{~cm}^{2}$ was placed in buffer solution of volume $20.0 \mathrm{~mL}$. The vessel was placed in a constant-temperature oven at 70 or $90^{\circ} \mathrm{C}$ for 1 to 10 days. The $\mathrm{pH}$ was measured before and after each test using an Orion Ross combination semi-micro electrode, calibrated with reference buffer solutions at $70^{\circ} \mathrm{C}$ or $90^{\circ} \mathrm{C}$. All pH measurements were carried out with the test or reference solution in a constant-temperature bath.

TABLE I. Buffer Compositions Used in $\mathrm{pH}$ Buffer Tests and Measured Buffer $\mathrm{pH}$ Values

\begin{tabular}{cccc}
\hline Buffer Composition & $\mathrm{pH}, 25^{\circ} \mathrm{C}$ & $\mathrm{pH}, 70^{\circ} \mathrm{C}$ & $\mathrm{pH}, 90^{\circ} \mathrm{C}$ \\
\hline $0.0095 \mathrm{~m} \mathrm{KHph}^{\mathrm{a}}+0.0027 \mathrm{~m} \mathrm{LiOH}$ & 4.85 & 5.01 & 5.07 \\
$0.0038 \mathrm{~m} \mathrm{KHph}^{\mathrm{a}}+00031 \mathrm{~m} \mathrm{LiOH}$ & 5.82 & 5.97 & 6.01 \\
$0.0263 \mathrm{~m} \mathrm{TRIS}^{\mathrm{b}}+0.010 \mathrm{~m} \mathrm{HNO}$ & 8.47 & 7.25 & 6.15 \\
$0.064 \mathrm{~m} \mathrm{H}_{3} \mathrm{BO}_{3}+0.010 \mathrm{~m} \mathrm{LiOH}$ & 8.39 & 8.10 & 7.94 \\
$0.012 \mathrm{~m} \mathrm{H}_{3} \mathrm{BO}_{3}+0.010 \mathrm{~m} \mathrm{LiOH}$ & 9.81 & 9.35 & 9.15 \\
$0.00098 \mathrm{~m} \mathrm{HNO}_{3}+0.0117 \mathrm{~m} \mathrm{LiOH}$ & 11.96 & 10.66 & 10.23 \\
\hline
\end{tabular}

${ }^{a}$ KHph: Potassium hydrogen phthalate.

b TRIS: Tris(hydroxymethyl)aminomethane.

The MCC-1 tests have been conducted at $90^{\circ} \mathrm{C}$ for $1,2,3,5,7$, and 10 days, or at $70^{\circ} \mathrm{C}$ for $3,5,7$, and 10 days. (Tests at $40^{\circ} \mathrm{C}$ are in progress.) The test durations were selected to be short enough that the rate of corrosion would be as close as possible to the forward rate. Results of MCC-1 tests with an alkali borosilicate glass at $90^{\circ} \mathrm{C}$ had previously shown that 3,5,7, and 10-day tests yield the forward rate [10]; tests at shorter durations may be affected by surface roughness, while tests at longer durations show the effect of the affinity term $\left(1-\mathrm{Q} /\left[\mathrm{H}_{4} \mathrm{SiO}_{4}\right]_{\mathrm{sat}}\right)$.

Termination of the tests required taking aliquots for $\mathrm{pH}$ measurement at the testing temperature and at $25^{\circ} \mathrm{C}$. Aliquots were also taken after filtration and acidification for inductively coupled plasma-atomic emission spectroscopy or for inductively coupled plasmamass spectroscopy. The vessels were then subjected to an acid stripping with $1 \% \mathrm{HNO}_{3}$ solution ; the concentrations of cations in the acid strip solutions were negligible. 


\section{RESULTS}

The concentration of silicon in solution after test termination provides the best measure of matrix dissolution of glass-bonded sodalite, since both glass binder and sodalite have high silicon concentrations. The measured Si concentrations in solutions from buffered MCC-1 tests with each material (glass binder, sodalite, and CWF) were used to calculate the normalized mass losses, $\mathrm{NL}(\mathrm{Si})=\left(\mathrm{m}-\mathrm{m}_{\mathrm{b}}\right) / \mathrm{f}_{\mathrm{Si}} \cdot \mathrm{S}$, where $\mathrm{m}$ is the mass of silicon in the test solution, $\mathrm{m}_{\mathrm{b}}$ is the mass of silicon in the experimental blank, $\mathrm{f}_{\mathrm{Si}}$ is the mass fraction of silicon in the material, and $\mathrm{S}$ is the sample surface area. At each temperature, the $\mathrm{NL}(\mathrm{Si})$ from tests at each buffer $\mathrm{pH}$ increased rapidly during the first three days, then increased more slowly to 10 days.

The normalized release rates, $\mathrm{NR}(\mathrm{Si})=\left[\mathrm{NL}\left(\mathrm{Si}, \mathrm{t}_{2}\right)-\mathrm{NL}\left(\mathrm{Si}, \mathrm{t}_{1}\right) /\left(\mathrm{t}_{2}-\mathrm{t}_{1}\right)\right.$, were calculated by linear regression of the 3- to 10-day releases for glass, sodalite, and CWF at $70^{\circ} \mathrm{C}$ and 1 - to 5-day releases at $90^{\circ} \mathrm{C}$; these release rates are listed in Table II. The logarithms of the $\mathrm{NR}(\mathrm{Si})$ data were plotted as a function of $\mathrm{pH}$ from tests at each temperature, as shown in Fig. 1. The logarithmic form of eq. (1) shows that the values of $\eta$ are the slopes of the regression lines in Fig. 1.

$$
\left.\log (\text { rate })=\log \mathrm{S}+\log \mathrm{k}_{0}+\eta \cdot \mathrm{pH}-\mathrm{E}_{\mathrm{a}} / \mathrm{RT}+\log \left(1-\mathrm{Q} /\left[\mathrm{H}_{4} \mathrm{SiO}_{4}\right]_{\mathrm{sat}}\right)\right\}
$$

These values of $\eta$ in the acidic and basic regions are listed in Table III.

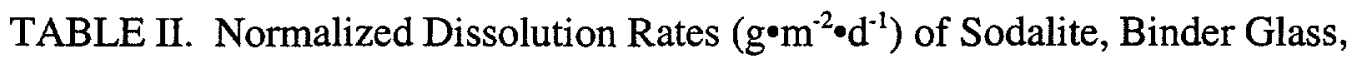
and Ceramic Waste Form (CWF) as a Function of $\mathrm{pH}$ at 70 and $90^{\circ} \mathrm{C}^{\mathrm{a}}$

\begin{tabular}{cccccc}
\hline $\mathrm{pH}$ & $\begin{array}{c}\text { Sodalite, } \\
90^{\circ} \mathrm{C}^{\mathrm{b}}\end{array}$ & Glass, $70^{\circ} \mathrm{C}$ & Glass, $90^{\circ} \mathrm{C}$ & $\mathrm{CWF}, 70^{\circ} \mathrm{C}$ & $\mathrm{CWF}, 90^{\circ} \mathrm{C}$ \\
\hline $5.0-5.2$ & $2.64 \pm 0.64$ & $0.025 \pm 0.002$ & $0.088 \pm 0.020$ & $1.39 \pm 0.15$ & $1.82 \pm 0.43$ \\
6.0 & $0.64 \pm 0.15$ & $0.0093 \pm 0.0019$ & $0.056 \pm 0.012$ & $0.48 \pm 0.02$ & $0.67 \pm 0.18$ \\
$6.9-7.0$ & $0.38 \pm 0.24$ & & $0.056 \pm 0.006$ & & $0.69 \pm 0.11$ \\
7.3 & & $0.016 \pm 0.002$ & & $0.19 \pm 0.03$ & \\
7.9 & $0.98 \pm 0.29$ & & $0.93 \pm 0.21$ & & $1.29 \pm 0.13$ \\
8.3 & & $0.22 \pm 0.01$ & & $0.40 \pm 0.03$ & \\
9.2 & $1.22 \pm 0.34$ & & $1.47 \pm 0.37$ & & $1.53 \pm 0.16$ \\
9.6 & & $0.50 \pm 0.02$ & & $0.50 \pm 0.03$ & \\
10.2 & $2.55 \pm 1.21$ & & $5.3 \pm 1.3$ & & $3.27 \pm 0.80$ \\
\hline
\end{tabular}

${ }^{\mathrm{a}}$ Uncertainties are standard errors.

${ }^{\mathrm{b}}$ Measurements at $70^{\circ} \mathrm{C}$ are in progress. 


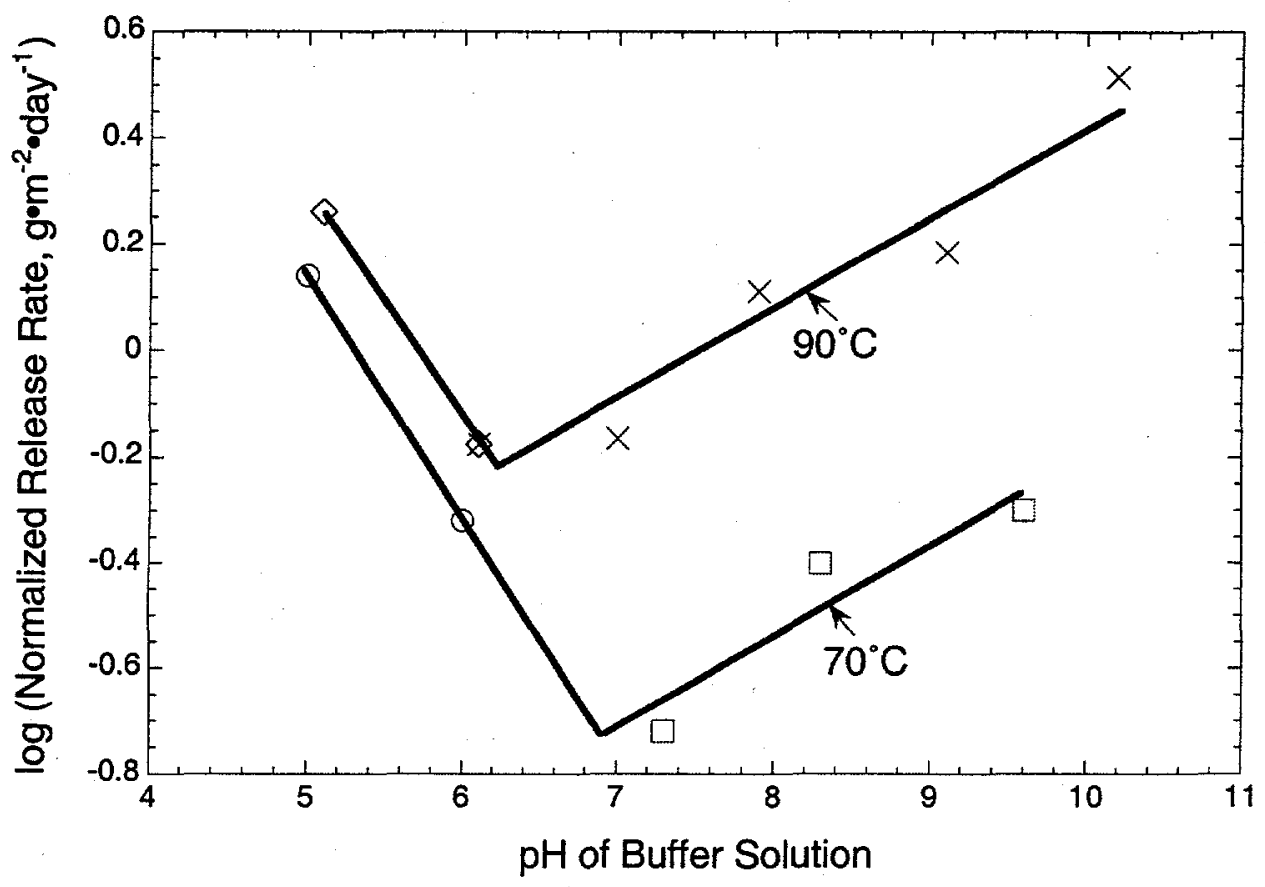

Fig. 1. Log (silicon release rate) from CWF as Function of $\mathrm{pH}$ in Buffered MCC-1 Tests at 70 and $90^{\circ} \mathrm{C}$.

TABLE III. Values of $\eta$ for Binder Glass, Sodalite, and CWF at 70 and $90^{\circ} \mathrm{C}$ (uncertainties of $\eta$ are standard errors)

\begin{tabular}{lcc}
\hline \multicolumn{1}{c}{ Material } & $\eta$ (acidic) & $\eta$ (basic) \\
\hline Glass $\left(70^{\circ} \mathrm{C}\right)$ & $-0.54^{*}$ & $0.63 \pm 0.24$ \\
Glass $\left(90^{\circ} \mathrm{C}\right)$ & $-0.20^{*}$ & $0.55 \pm 0.15$ \\
Salt-loaded Sodalite $\left(70^{\circ} \mathrm{C}\right)$ & In progress & In progress \\
Salt-loaded Sodalite $\left(90^{\circ} \mathrm{C}\right)$ & $-0.47 \pm 0.12$ & $0.23 \pm 0.05$ \\
CWF $\left(70^{\circ} \mathrm{C}\right)$ & $-0.46^{*}$ & $0.18 \pm 0.07$ \\
CWF $\left(90^{\circ} \mathrm{C}\right)$ & $-0.44^{*}$ & $0.17 \pm 0.03$ \\
\hline
\end{tabular}

*2-point fit; standard error estimated as \pm 0.2

\section{DISCUSSION}

Controlled-pH MCC-1 tests in the $\mathrm{pH}$ 5-10 region show normalized silicon mass losses that increase with test duration, rapidly in the first few days and then more slowly during 5-10 day test durations. Tentative dissolution rates have been calculated in the acidic and basic regions at 70 and $90^{\circ} \mathrm{C}$. The dissolution rates are lower at $70^{\circ} \mathrm{C}$ than at $90^{\circ} \mathrm{C}$ at all $\mathrm{pH}$ values. The dissolution rates have a $\mathrm{V}$-shaped behavior with minima at neutral solution $\mathrm{pH}$ values and increase as solution $\mathrm{pH}$ becomes more acidic or more basic.

The dissolution rates are consistent with dissolution rates for nuclear waste glasses and aluminosilicate minerals. The $\mathrm{pH}$ dependence of the dissolution of glass, salt-loaded sodalite, and CWF display the V-shape behavior reported for nuclear waste glass [4]. For the CWF as 
well as its components, the rate of dissolution is at a minimum near the point of neutral $\mathrm{pH}$, which is 7.00 at $25^{\circ} \mathrm{C}$, decreasing to 6.40 at $70^{\circ} \mathrm{C}$ and 6.21 at $90^{\circ} \mathrm{C}$ [11]. The results for saltloaded sodalite are in fair agreement with dissolution tests of natural sodalite as a function of $\mathrm{pH}$ at $50^{\circ} \mathrm{C}: \eta$ (acidic) $=-0.6$ and $\eta$ (basic) $=0.06$ [12]. Other studies found a "flattened V" $\mathrm{pH}$ dependence. For example, Knauss and Wolery reported the dissolution rate of albite to be independent of $\mathrm{pH}$ over the range $\mathrm{pH} 3$ to 8 [2] and the dissolution rate of muscovite to be $\mathrm{pH}$ independent between $\mathrm{pH} 5$ and 7 [3]. Other aluminosilicate mineral dissolution rates are $\mathrm{pH}$ dependent over a wider $\mathrm{pH}$ range [5].

The dissolution rate of the CWF is expected to be a linear combination of the dissolution of its two components in the absence of synergism (interactive effects) between glass and sodalite dissolution. The $\mathrm{pH}$ dependence of the dissolution rate, $\eta$, is also expected to be a linear combination of the glass and sodalite rates, weighted in terms of the CWF composition of 75 mass $\%$ salt-loaded sodalite and 25 mass $\%$ glass. The results of Table III at $90^{\circ} \mathrm{C}$ indicate that the $\eta(\mathrm{CWF})$ values derived from measured NL(Si,CWF) are consistent with the $\eta(\mathrm{CWF})$ calculated from $\mathrm{NL}(\mathrm{Si}$, sodalite) and $\mathrm{NL}(\mathrm{Si}$, glass) weighted in the 3:1 ratio of sodalite to glass in the CWF. This weighting yields calculated $\eta$ values for CWF of -0.40 in the acidic region and 0.31 in the basic region.

Additional buffered MCC-1 tests are being carried out at lower and higher $\mathrm{pH}$ values to better define the $\eta$ values. Additional tests are also in progress at $40^{\circ} \mathrm{C}$. Values of $\eta$ at three temperatures will permit the calculation of $E_{a}$, which reflects the temperature dependence of the dissolution rate.

Other studies have found that the presence of $\mathrm{Si}$ in the neutral and basic $\mathrm{pH}$ range reduced the initial dissolution rate of waste glasses by a factor of 20 [7]. In the acidic region, $\mathrm{Al}$ was found to reduce the dissolution rate. We have initiated tests to determine the effect of dissolved $\mathrm{Si}$ and $\mathrm{Al}$ concentration on the dissolution of the glass and sodalite components of the CWF.

\section{ACKNOWLEDGMENTS}

The authors acknowledge timely and thorough analytical support by Doris Huff, Yifen Tsai, and Stephen Wolf. Research supported by U.S. Department of Energy, Nuclear Energy Research and Development Program, under contract W-31-109-ENG-38.

\section{REFERENCES}

1. ANL-NT-119, Ceramic Waste Form Handbook, L. R. Morss, compiler, 1999.

2. K. G. Knauss and T. J. Wolery, "Dependence of Albite Dissolution Kinetics of pH and Time at $25^{\circ}$ and $70^{\circ} \mathrm{C}, "$ Geochim. Cosmochim. Acta 50, 2481-2497 (1986)

3. K. G. Knauss and T. J. Wolery, "Muscovite Dissolution as a Function of $\mathrm{pH}$ and Time at $70^{\circ} \mathrm{C}, "$ Geochim. Cosmochim. Acta 53, 1493-1501 (1989)

4. K. G. Knauss, W. L. Bourcier, K. D. McKeegan, C. I. Merzbacher, S. N. Nguyen, F. J. Ryerson, D. K. Smith, H. C. Weed, "Dissolution Kinetics of a Simple Analogue Nuclear Waste Glass as a Function of pH, Time, and Temperature," Mat. Res. Soc. Symp. Proc., 176, 371-381 (1990)

5. E. H. Oelkers, J. Schott, J. Devidal, "The Effect of Aluminum, pH, and Chemical Affinity on the Rates of Aluminosilicate Dissolution Reactions. Geochim. Cosmochim. Acta 58, 2011-2024 (1994)

6. P. K. Abraitis, D. J. Vaughan, F. R.Livens, J. Monteith, D. P. Trivedi, J. S. Small, "Dissolution of a Complex Borosilicate Glass at $60^{\circ} \mathrm{C}$ : The Influence of $\mathrm{pH}$ and Proton 
Absorption on the Congruence of Short-Term Leaching," Mat. Res. Soc. Symp. Proc. 506, 4754 (1998)

7. W. Bourcier, “Affinity Functions for Modeling Glass Dissolution Rates," UCRL-JC-131186 (1998)

8. P. Aagaard and H. C. Helgeson, "Thermodynamic and Kinetic Constraints on Reaction Rates among Mineral and Aqueous Solutions, I. Theoretical Considerations," Am. J. Science, 282, 237-285 (1982)

9. American Society for Testing and Materials, "Annual Book of ASTM Standards," 12.01, Standard Test Method for Static Leaching of Monolithic Waste Forms for Disposal of Radioactive Waste, C1220-98, pp. 1-16 (1998)

10. B. P. McGrail, W. L. Ebert, A. J. Bakel, D. K. Peeler, "Measurement of Kinetic Rate Law Parameters on a Na-Ca-Al Borosilicate Glass for Low-Activity Waste," J. Nucl. Materials 249, 1765-189 (1997)

11. H. S. Harned and B. B. Owen, The Physical Chemistry of Electrolytic Solutions, $3^{\text {rd }}$ ed. (Reinhold, New York, 1958), pp. 643-649.

12. K. Montgomery, "The Synthesis and Dissolution of Sodalite: Implications for Nuclear Waste Disposal," M. Sc. Thesis, Dept. of Geology, University of Alberta, Canada (1986) 